\title{
Factors Associated with Primary Postpartum Hemorrhage in Elderly Women Undergoing Repeated Cesarean Deliveries
}

\section{Yan Yang \\ Jiajia $\mathrm{He}$ \\ $\mathrm{Na}$ Deng}

Department of Obstetrics, Dianjiang Country People's Hospital of Chongqing, Chongqing, 408300, People's Republic of China
Correspondence: Yan Yang Department of Obstetrics, Dianjiang Country People's Hospital of Chongqing, Chongqing, 408300, People's Republic of China

Tel/Fax +86 23-85653335

Email obstetricsyan@163.com
Purpose: The aim of this study was to analyze the risk factors for primary postpartum hemorrhage in elderly parturients undergoing repeated cesarean delivery (PHEPWRCD).

Participants and Methods: The clinical data of 1675 elderly parturients who underwent repeated cesarean delivery in our hospital from May 2011 to March 2020 were retrospectively collected for analysis. The women were divided into a postpartum hemorrhage group (116 individuals) and a nonpostpartum hemorrhage group (1559 individuals). We analyzed the association of maternal age, maternal history, pregnancy complications, placenta and other factors with postpartum hemorrhage in elderly women who underwent repeated cesarean delivery and screened out independent risk factors by multivariate logistic regression analysis.

Results: The incidence rate of PHEPWRCD was 6.92\% (116/1675). Using single-factor analysis of variance, we found that maternal age $(\mathrm{p}=0.012)$, the number of pregnancies $(p=0.007)$, the number of cesarean deliveries $(p<0.001)$, fetal position $(p<0.001)$, fetal macrosomiaren $(\mathrm{p}<0.001)$, placental attachment position $(\mathrm{p}<0.001)$, placenta previa $(\mathrm{p}<0.001)$, and placental implantation $(\mathrm{p}<0.001)$ were significantly associated with PHEPWRCD. Multivariate logistic regression analysis showed that the number of cesarean deliveries $(\mathrm{OR}=2.457,95 \% \mathrm{CI}=1.453-4.540, \mathrm{P}=0.013)$, placenta previa $(\mathrm{OR}=11.741,95 \%$ $\mathrm{CI}=5.874-26.078, \mathrm{P}<0.001)$, placenta implantation $(\mathrm{OR}=6.844,95 \% \mathrm{CI}=3.514-14.873$, $\mathrm{P}<0.001)$, placental attachment position $(\mathrm{OR}=2.421,95 \% \mathrm{CI}=1.275-3.917, \mathrm{P}=0.009)$ and fetal position $(\mathrm{OR}=5.722,95 \% \mathrm{CI}=3.817-16.577, \mathrm{P}<0.001)$ were independent risk factors for PHEPWRCD.

Conclusion: This study found that the number of cesarean deliveries, placental attachment, placental previa, and placental implantation are independent risk factors for PHEPWRCD.

Keywords: postpartum hemorrhage, repeated cesarean delivery, elderly parturients, risk factors

\section{Introduction}

As a serious postpartum complication, postpartum hemorrhage threatens the life safety of the mother. According to statistics reported by the World Health Organization, the number of maternal deaths due to bleeding accounts for approximately $25 \%$ of the total number of maternal deaths. ${ }^{1,2}$ Studies have shown that both advanced age and cesarean delivery increase the risk of postpartum hemorrhage. ${ }^{3,4}$ The incidence of cesarean delivery in the United States is $20-30.5 \% .^{3-5}$ In recent years, China has adopted strict management measures, and the incidence of cesarean section has dropped to $34.9 \%$. 
However, with the opening of China's comprehensive second child policy, the number of older women undergoing cesarean section is increasing. ${ }^{7}$ Postpartum hemorrhage is the most common independent cause of maternal death. Berg et al analyzed data from pregnant women who gave birth in hospitals in the United States from 1993-1997 and 2001-2005, and the incidence of postpartum hemorrhage ranged from $2.0 \%$ to $2.6 \%{ }^{30}$ This difference is not just a question of medical standards but, more importantly, a question of maternal management and prevention strategies. ${ }^{8}$ Reducing the incidence of postpartum hemorrhage and maternal mortality is an important issue that obstetricians and gynecologists need to face. ${ }^{5,6,9}$ Since both advanced age and cesarean section increase the risk of primary postpartum hemorrhage, analysis of risk factors for postpartum hemorrhage in elderly parturients undergoing repeated cesarean delivery (PHEPWRCD) is helpful to identify potential postpartum hemorrhage patients in advance and take active intervention measures. In this study, we conducted a retrospective analysis of PHEPWRCD to provide a clinical reference.

\section{Methods and Participants Case Collection}

The clinical data of 1675 elderly parturients who underwent repeated cesarean delivery in the Department of Obstetrics, Dianjiang Country People's Hospital of Chongqing Hospital, from May 2011 to March 2020 were retrospectively collected for analysis. The inclusion criteria were as follows: age $\geq 35$ years old; a history of cesarean section; and the use of cesarean section during the current visit. Exclusion criteria: intrauterine fetal death; twin pregnancy; gestational age $<28$ weeks; abnormal coagulation function. The women were divided into a postpartum hemorrhage group $(\mathrm{n}=116)$ and a nonpostpartum hemorrhage group $(\mathrm{n}=1559)$. All our parturients were treated according to standard postpartum hemorrhage prevention and treatment measures. ${ }^{8,9}$ The study was performed in accordance with the ethical standards of the institutional and/or national research committee and with the 1964 Helsinki Declaration and its later amendments or comparable ethical standards. This study was approved by the Ethics Committee of Dianjiang County People's Hospital in Chongqing. All patients included in the study and their families signed relevant informed consent forms.

\section{Collection of Clinical Data}

The clinical data of maternal age, maternal BMI, natural delivery times, previous cesarean section times, abortion times, induced labor times, pregnancy vaginal bleeding times, placental attachment position, placenta previa, placenta accreta, gestational hypertension disease, gestational diabetes mellitus, fetal position, gestational weeks of delivery and neonatal weight were analyzed. Primary postpartum hemorrhage after cesarean section refers to the amount of bleeding $\geq 1000 \mathrm{~mL}$ within 24 hours after delivery of the fetus. ${ }^{8}$ Complete placenta previa means that the placental tissue completely covers the cervical ostium. Incomplete placenta previa includes a low placenta (placenta attached to the lower uterus, with a margin $<$ $2 \mathrm{~cm}$ from the cervical ostium), marginal placenta previa (the lower edge of placental tissue reaches the cervical ostia), and partial placenta previa (placental tissue covering part of the cervix). ${ }^{10,11}$

\section{Results}

\section{Single Factor Analysis of Risk Factors for PHEPWRCD}

As shown in Table 1, the incidence rate of PHEPWRCD was $6.92 \%(116 / 1675)$. Using single-factor analysis of variance, we found that the maternal age $(38.41 \pm 6.78 \mathrm{VS}$ $37.11 \pm 5.48, \mathrm{P}=0.012)$, number of pregnancies $(\mathrm{P}=$ 0.007), number of cesarean delivery $(P<0.001)$, fetal position $(\mathrm{P}<0.001)$, Fetal macrosomia $(\mathrm{P}=0.024)$, placental attachment position $(\mathrm{P}<0.001)$, placenta previa $(\mathrm{P}<$ $0.001)$, and placental implantation $(\mathrm{P}<0.001)$ are risk factors for PHEPWRCD. However, the number of induced labor $(p=0.217)$, the number of miscarriages $(p=0.427)$, the gestational week of delivery $(37.12 \pm 0.46$ vs 37.42 $\pm 0.31, p=0.629$ ), the number of vaginal bleeding during pregnancy $(p=0.427)$, hypertension during pregnancy $(p=0.418)$, gestational diabetes $(p=0.807)$, BMI $(27.56$ \pm 1.28 vs $27.26 \pm 1.45, \mathrm{p}=0.305)$ of pregnant women and gestational diabetes $(p=0.807)$ are not risk factors for PHEPWRCD.

\section{Multiple Logistic Regression Model Analysis of Risk Factors for PHEPWRCD} As shown in Table 2, the results of multivariate logistic regression analysis showed that the number of cesarean delivery $(\mathrm{OR}=2.457,95 \% \mathrm{CI}=1.453-4.540, \mathrm{P}=0.013)$, placenta previa $(\mathrm{OR}=11.741,95 \% \mathrm{CI}=5.874-26.078$, $\mathrm{P}<0.001)$, placenta implantation $(\mathrm{OR}=6.844,95 \% \mathrm{CI}=$ 
Table I Univariate Analysis of Risk Factors for Postpartum Hemorrhage in Elderly Parturient Women Undergoing Repeated Cesarean Delivery

\begin{tabular}{|c|c|c|c|c|c|}
\hline Variable & & $\begin{array}{l}\text { Postpartum } \\
\text { Hemorrhage Group } \\
(n=116)\end{array}$ & $\begin{array}{l}\text { Non-Postpartum } \\
\text { Hemorrhage Group } \\
(n=1599)\end{array}$ & $\operatorname{RR}(95 \% \mathrm{Cl})$ & $\begin{array}{l}\text { Adjusted } \\
\text { P value }\end{array}$ \\
\hline Maternal age (years) & & $38.4 I \pm 6.78$ & $37.11 \pm 5.48$ & - & 0.012 \\
\hline BMI of maternal $\left(\mathrm{kg} / \mathrm{m}^{2}\right)$ & & $27.56 \pm 1.28$ & $27.26 \pm 1.45$ & - & 0.305 \\
\hline Number of pregnancies & $\begin{array}{l}1 \\
2 \\
\geq 3\end{array}$ & $\begin{array}{l}19(16.38 \%) \\
45(38.79 \%) \\
52(44.83 \%)\end{array}$ & $\begin{array}{l}512(32.02 \%) \\
590(36.89 \%) \\
497(31.08 \%)\end{array}$ & - & 0.007 \\
\hline $\begin{array}{l}\text { Number of cesarean } \\
\text { delivery }\end{array}$ & $\begin{array}{l}1 \\
2 \\
\geq 3\end{array}$ & $\begin{array}{l}88(75.86 \%) \\
16(13.80) \\
12(10.34 \%)\end{array}$ & $\begin{array}{l}1452(90.81 \%) \\
130(8.13 \%) \\
17(1.06 \%)\end{array}$ & - & $<0.001$ \\
\hline Number of miscarriages & $\begin{array}{l}0 \\
1 \\
2 \\
\geq 3\end{array}$ & $\begin{array}{l}33(28.45 \%) \\
51(43.96 \%) \\
23(19.84 \%) \\
9(7.75 \%)\end{array}$ & $\begin{array}{l}523(32.72 \%) \\
685(42.83 \%) \\
289(18.07 \%) \\
102(6.38)\end{array}$ & - & 0.427 \\
\hline $\begin{array}{l}\text { The number of induced } \\
\text { labor }\end{array}$ & $\begin{array}{l}0 \\
1 \\
\geq 2\end{array}$ & $\begin{array}{l}101(87.06 \%) \\
10(8.62 \%) \\
5(4.31 \%)\end{array}$ & $\begin{array}{l}\text { I } 447(90.49 \%) \\
\mid 46(9.13 \%) \\
6(3.75 \%)\end{array}$ & - & 0.217 \\
\hline Fetal position & $\begin{array}{l}\text { Head position } \\
\text { Breech } \\
\text { position } \\
\text { Horizontal } \\
\text { position }\end{array}$ & $\begin{array}{l}78(67.24 \%) \\
18(15.52 \%) \\
20(17.24 \%)\end{array}$ & $\begin{array}{l}1439(89.99 \%) \\
96(6.01 \%) \\
64(4.00 \%)\end{array}$ & - & $<0.001$ \\
\hline $\begin{array}{l}\text { Gestational weeks of } \\
\text { delivery }\end{array}$ & & $37.12 \pm 0.46$ & $37.42 \pm 0.31$ & - & 0.629 \\
\hline Fetal macrosomia & $\begin{array}{l}\text { Yes } \\
\text { No }\end{array}$ & $\begin{array}{l}\text { II (9.48\%) } \\
106(90.52 \%)\end{array}$ & $\begin{array}{l}88(5.50 \%) \\
15 I \mid(94.50 \%)\end{array}$ & I.78[0.924,3.437] & 0.024 \\
\hline $\begin{array}{l}\text { Number of vaginal } \\
\text { bleeding during } \\
\text { pregnancy }\end{array}$ & $\begin{array}{l}0 \\
1 \\
2 \\
\geq 3\end{array}$ & $\begin{array}{l}80(68.95 \%) \\
32(27.59 \%) \\
18(15.51 \%) \\
4(3.45 \%)\end{array}$ & $\begin{array}{l}\text { II } 98 \text { (74.92\%) } \\
\text { I } 79 \text { (II.I3\%) } \\
159(9.89 \%) \\
64(4.01 \%)\end{array}$ & - & 0.175 \\
\hline $\begin{array}{l}\text { Placenta attachment } \\
\text { position }\end{array}$ & $\begin{array}{l}\text { Posterior } \\
\text { uterine wall } \\
\text { Other } \\
\text { location }\end{array}$ & $\begin{array}{l}21(18.10 \%) \\
95(81.89 \%)\end{array}$ & $\begin{array}{l}662(41.41 \%) \\
937(58.59 \%)\end{array}$ & $0.3 \mid[0.193,0.507]$ & $<0.001$ \\
\hline Placenta previa & $\begin{array}{l}\text { Non- } \\
\text { placental } \\
\text { placenta } \\
\text { Incomplete } \\
\text { placenta } \\
\text { previa } \\
\text { Complete } \\
\text { placenta } \\
\text { previa }\end{array}$ & $\begin{array}{l}28(24.14 \%) \\
15(12.93 \%) \\
73(62.93 \%)\end{array}$ & $\begin{array}{l}\text { I } 232(77.05 \%) \\
68(4.25 \%) \\
300(\mid 8.76 \%)\end{array}$ & - & $<0.001$ \\
\hline
\end{tabular}


Table I (Continued).

\begin{tabular}{|l|l|l|l|l|l|}
\hline Variable & & $\begin{array}{l}\text { Postpartum } \\
\text { Hemorrhage Group } \\
(\mathbf{n = 1 1 6 )}\end{array}$ & $\begin{array}{l}\text { Non-Postpartum } \\
\text { Hemorrhage Group } \\
\text { (n=1599) }\end{array}$ & $\begin{array}{l}\text { Adjusted } \\
\text { P value }\end{array}$ \\
\hline Placenta implantation & $\begin{array}{l}\text { No } \\
\text { Yes }\end{array}$ & $\begin{array}{l}54(46.55 \%) \\
62(53.44 \%)\end{array}$ & $\begin{array}{l}\text { I3II (8I.99\%) } \\
288(18.01 \%)\end{array}$ & $0.19[0.13,0.28]$ & $<0.001$ \\
\hline $\begin{array}{l}\text { Hypertension during } \\
\text { pregnancy }\end{array}$ & $\begin{array}{l}\text { No } \\
\text { Yes }\end{array}$ & $\begin{array}{l}99(85.34 \%) \\
17(14.66 \%)\end{array}$ & $\begin{array}{l}1415(88.49 \%) \\
184(11.51 \%)\end{array}$ & $0.75[0.442,1.296]$ & 0.418 \\
\hline Gestational diabetes & $\begin{array}{l}\text { No } \\
\text { Yes }\end{array}$ & $\begin{array}{l}86(74.14 \%) \\
30(25.86)\end{array}$ & $\begin{array}{l}1274(77.98 \%) \\
325(20.32 \%)\end{array}$ & $0.73[0.474,1.128]$ & 0.807 \\
\hline
\end{tabular}

Table 2 Multiple Logistic Regression Model Analysis of Risk Factors for Postpartum Hemorrhage in Elderly Parturient Women Undergoing Repeated Cesarean Delivery

\begin{tabular}{|l|l|l|l|}
\hline Risk Factors & Adjusted OR Value & $\mathbf{9 5 \%} \mathbf{~ C l}$ & P value \\
\hline Maternal age (years) & 1.634 & $0.869-2.011$ & 0.324 \\
Number of pregnancies & 2.342 & $1.251-4.231$ & 0.127 \\
Number of cesarean delivery & 3.312 & $2.249-5.912$ & 0.013 \\
Fetal position & 5.022 & $3.87-13.543$ & $<0.001$ \\
Fetal macrosomia & 1.864 & $1.005-4.275$ & 0.081 \\
Placenta attachment position & 4.011 & $2.25-8.27$ & 0.009 \\
Placenta previa & 9.702 & $5.874-21.01$ & $<0.001$ \\
Placenta implantation & 6.244 & $3.54-10.81$ & $<0.001$ \\
\hline
\end{tabular}

3.54-14.873, $\mathrm{P}<0.001$ ), placenta attachment position (OR $=2.421,95 \%$ CI $1.275-3.917, \mathrm{P}=0.009)$ and fetal position $(\mathrm{OR}=5.722,95 \% \mathrm{CI}=3.87-16.577, \mathrm{P}<0.001)$ is an independent risk factor for PHEPWRCD.

\section{Univariate Logistic Regression Analysis of Risk Factors for PHEPWRCD in Fetal Position}

As shown in Table 3, compared with the head position, the risk of PHEPWRCD in the breech position $(\mathrm{OR}=5.38$, $95 \% \mathrm{CI}=3.752-11.237, \mathrm{P}=0.005)$ and the transverse position $(\mathrm{OR}=10.79,95 \% \mathrm{CI}=5.872-23.491, \mathrm{P}<0.001)$ has increased by 5.381 times and 10.792 times, respectively.

Table 3 Univariate Logistic Regression Analysis of Risk Factors for Postpartum Hemorrhage in Elderly Parturient Women Undergoing Repeated Cesarean Delivery in Fetal Position

\begin{tabular}{|l|l|l|l|}
\hline Risk Factors & OR Value & $\mathbf{9 5 \%} \mathbf{C l}$ & P value \\
\hline Head position & - & - & - \\
Breech position & 5.381 & $3.752-11.237$ & 0.005 \\
Horizontal position & 10.792 & $5.872-23.491$ & $<0.001$ \\
\hline
\end{tabular}

\section{Univariate Logistic Regression Analysis of Risk Factors for PHEPWRCD in Placenta Previa}

As shown in Table 4, compared with non placenta previa, the risk of PHEPWRCD with incomplete placenta previa $(\mathrm{OR}=9.842,95 \% \mathrm{CI}=6.014-22.274, \mathrm{P}<0.001)$ and complete placenta previa $(\mathrm{OR}=15.613,95 \% \mathrm{CI}=8.751-$ $30.405, \mathrm{P}<0.001)$ increased by 9.8 times and 15.6 times, respectively.

\section{Discussion}

Postpartum hemorrhage is the most important independent cause of maternal death. To reduce the incidence of postpartum hemorrhage and maternal mortality, early

Table 4 Univariate Logistic Regression Analysis of Risk Factors for Postpartum Hemorrhage in Elderly Parturient Women Undergoing Repeated Cesarean Delivery in Placenta Previa

\begin{tabular}{|l|l|c|c|}
\hline Risk Factors & OR Value & $\mathbf{9 5 \%} \mathbf{~ C I}$ & P value \\
\hline Non-placental placenta & - & - & - \\
Incomplete placenta previa & 9.842 & $6.014-22.274$ & $<0.001$ \\
Complete placenta previa & 15.613 & $8.751-30.405$ & $<0.001$ \\
\hline
\end{tabular}


prediction of postpartum hemorrhage has become an important problem for clinicians. ${ }^{8,12,13}$ The incidence of postpartum hemorrhage in the United States ranges from $2.0 \%$ to $2.6 \%{ }^{8,12,13}$ In this study, the prevalence of PHEPWRCD was approximately $6.92 \%$, which was much higher than the prevalence of postpartum hemorrhage reported in the literature of women who underwent natural delivery (the prevalence ranged from $2.0 \%$ to $2.6 \%)^{8,12,13}$ Compared with natural delivery, cesarean section causes more damage to the uterus, and the formation of uterine scars is unfavorable to the development of the placenta, which increases the possibility of uterine atony and placental-related diseases. In addition, the physical function and pregnancy ability of elderly women decreased, which may be the reason why elderly women who undergo a cesarean section are more prone to postpartum hemorrhage. Postpartum hemorrhage is the most important independent cause of maternal death. In view of the high incidence rate of PHEPWRCD, it is of great clinical significance to analyze the risk factors for PHEPWRCD and reduce the incidence of PHEPWRCD. In this study, our logistic regression analysis showed that placental-related factors (placental attachment position, placenta previa, placenta accreta) were important independent risk factors for PHEPWRCD. ${ }^{14}$ Belachew et al reported that the anterior placenta may increase the risk of postpartum hemorrhage for women with a previous cesarean section history. ${ }^{15}$ In this study, we found that for older women undergoing cesarean delivery, compared with the placenta attached to the posterior wall of the uterus, the risk of postpartum hemorrhage increased by 4.421-fold $(\mathrm{OR}=4.421,95 \% \mathrm{CI}=2.275-8.917, \mathrm{P}=$ 0.009), which is similar to the findings reported by Belachew. ${ }^{15}$ The effect of placenta previa on postpartum hemorrhage has been mentioned in many studies, ${ }^{15-17}$ but the difference between the effects of incomplete placenta previa and complete placenta previa on postpartum hemorrhage is rarely reported. In this study, we found that placenta previa $(\mathrm{OR}=11.743,95 \% \mathrm{CI}=5.874-26.078$, $\mathrm{P}<0.001)$ was an independent risk factor for PHEPWRCD. In addition, our univariate logistic regression analysis also found that compared with nonplacenta previa, the risk of PHEPWRCD with incomplete placenta previa $(\mathrm{OR}=9.842,95 \% \mathrm{CI}=6.014-22.274, \mathrm{P}<0.001)$ and complete placenta previa $(\mathrm{OR}=15.613,95 \% \mathrm{CI}=$ $8.751-30.405, \mathrm{P}<0.001)$ increased by 9.842 -fold and 15.613-fold, respectively. Therefore, we suggest that placenta previa should be classified and evaluated to reduce the risk of PHEPWRCD. Studies have shown that cesarean section is one of the three major factors causing placenta accreta in pregnancy again, and placenta accreta is a risk factor for postpartum hemorrhage. ${ }^{18-20}$ Because placental tissue is implanted into the myometrium, the number and function of uterine smooth muscle cells are damaged, resulting in fatigue and uncoordinated contraction of the uterus, which in turn leads to postpartum hemorrhage. In this study, we also found that placental implantation $(\mathrm{OR}=$ $6.844,95 \% \mathrm{CI}=3.54-14.873, \mathrm{P}<0.001)$ was an independent risk factor for PHEPWRCD.

Previous studies suggest that maternal age, number of maternal births, and child size are risk factors for postpartum hemorrhage. ${ }^{21,22}$ In this study, our univariate analysis found that maternal age, number of maternal births, and fetal macrosomiaren were significantly associated with PHEPWRCD. Although these factors have not been shown to be independently related to PHEPWRCD in multivariate logistic regression analysis, they still have a suggestive role in the occurrence of postpartum hemorrhage. In clinical practice, maternal cesarean delivery for older women, multiple mothers and large fetuses still requires close attention. In this study, we found that the number of cesarean sections and fetal position are independent risk factors for PHEPWRCD. This result has rarely been reported in previous studies. Studies suggest that multiple cesarean sections will cause uterine scarring and placenta implantation during pregnancy, and these factors will affect the contractility of uterine muscles, which in turn will cause postpartum hemorrhage. ${ }^{23,24}$ Previous studies have suggested that the fetal lateral position can increase the probability of postpartum complications. ${ }^{25-27}$ In this study, univariate logistic regression analysis showed that compared with head position, the risk of PHEPWRCD in breech position $(\mathrm{OR}=5.381,95 \% \mathrm{CI}=3.752-11.237, \mathrm{P}=$ $0.005)$ and transverse position $(\mathrm{OR}=10.792,95 \% \mathrm{CI}=$ 5.872-23.491, $\mathrm{P}<0.001)$ increased by 5.381-fold and 10.792-fold, respectively. The possible reason for this result is that compared with the head position, the breech position and the lateral position are more likely to cause difficulty in delivering the fetus during cesarean section. The resulting impact on uterine contraction may be the main reason for the abnormal fetal position to increase the risk of postpartum hemorrhage. Previous studies have suggested that gestational hypertension, gestational diabetes and maternal BMI are closely related to postpartum hemorrhage, but in this study, we did not find that gestational hypertension, gestational diabetes, and maternal 
BMI are not risk factors for PHEPWRCD. ${ }^{28,29}$ This result may be due to race, age, and individual differences in the study.

This study has some limitations. First, the study sample is relatively small, and the results of the study need to be further confirmed by prospective studies with large samples. Second, this study is a single-center regression study, and multicenter studies can obtain accurate clinical reference materials. Third, due to the characteristics of surgical proficiency and population differences, the results of this study may have inherent errors. Fourth, this study has all the limitations and risks of bias inherent in the study design. Fifth, the lack and incompleteness of the patient drug use and treatment data resulted in partial bias of the results. Sixth, due to the lack of iron index data, there is inherent error in the incidence rate of PHEPWRCD.

\section{Conclusion}

However, this study found that the number of cesarean sections, placenta previa, placenta implantation, placenta attachment position and fetal position are independent risk factors for PHEPWRCD. In view of the above risk factors, the preventive measures we recommend are as follows. First, the abovementioned high-risk factors should be identified in advance, and emergency plans should be made for bleeding before cesarean sections. Second, the identification of intraoperative bleeding should be strengthened to prevent and treat bleeding. Third, strengthening teamwork, especially placenta previa, requires the cooperation of neonatology to promote rapid neonatal resuscitation. Fourth, the management of intraoperative and postoperative uterine muscle contraction should be strengthened, and women should undergo close postoperative monitoring.

\section{Abbreviations}

PHEPWRCD, postpartum hemorrhage in elderly parturients undergoing repeated cesarean delivery; OR, odds ratio; $\mathrm{CI}$, confidence interval.

\section{Author Contributions}

All authors made a significant contribution to the work reported, whether that is in the conception, study design, execution, acquisition of data, analysis, and interpretation, or in all of these areas; took part in drafting, revising, or critically reviewing the article; gave final approval of the version to be published; agreed on the journal to which the article has been submitted, and agree to be accountable for all aspects of the work.

\section{Funding}

The authors received no specific funding for this work.

\section{Disclosure}

The authors declare no competing interests.

\section{References}

1. Say L, Chou D, Gemmill A. Global causes of maternal death: a WHO systematic analysis. Lancet Glob Health. 2014;2(6):e323-e333. doi:10.1016/S2214-109X(14)70227-X

2. Maswime S, Buchmann E. A systematic review of maternal near miss and mortality due to postpartum hemorrhage. Int J Gynaecol Obstet. 2017;137(1):1-7. doi:10.1002/ijgo.12096

3. Sebghati M, Chandraharan E. An update on the risk factors for and management of obstetric haemorrhage. Womens Health. 2017;13 (2):34-40. doi:10.1177/1745505717716860

4. Andrikopoulou M, D'Alton ME. Postpartum hemorrhage: early identification challenges. Semin Perinatol. 2019;43(1):11-17. doi:10.1053/j.semperi.2018.11.003

5. Li H, Luo S, Trasande L. Geographic variations and temporal trends in cesarean delivery rates in China, 2008-2014. JAMA. 2017;317 (1):69-76. doi:10.1001/jama.2016.18663

6. Betrán AP, Ye J, Moller AB. The increasing trend in caesarean section rates: global, regional and national estimates: 1990-2014. PLoS One. 2016;11(2):e0148343. doi:10.1371/journal.pone.0148343

7. Long Q, Kingdon C, Yang F. Prevalence of and reasons for women's, family members', and health professionals' preferences for cesarean section in china: a mixed-methods systematic review. PLoS Med. 2018;15(10):e1002672. doi:10.1371/journal.pmed.1002672

8. Evensen A, Anderson JM, Fontaine P. Postpartum hemorrhage: prevention and treatment. Am Fam Physician. 2017;95(7):442-449.

9. Dahlke JD, Mendez-Figueroa H, Maggio L, et al. Prevention and management of postpartum hemorrhage: a comparison of 4 national guidelines. Am J Obstet Gynecol. 2015;213(1):76.e1-76.e10. doi:10.1016/j.ajog.2015.02.023

10. Ishibashi H, Miyamoto M, Soyama H, et al. Marginal sinus placenta previa is a different entity in placenta previa: a retrospective study using magnetic resonance imaging. Taiwan $J$ Obstet Gynecol. 2018;57(4):532-535. doi:10.1016/j.tjog.2018.06.009

11. Garofalo A, Pilloni E, Alemanno MG, et al. Ultrasound accuracy in prenatal diagnosis of abnormal placentation of posterior placenta previa. Eur J Obstet Gynecol Reprod Biol. 2019;242:86-91. doi:10.1016/j.ejogrb.2019.09.021

12. Santana DS, Cecatti JG, Surita FG. Twin pregnancy and severe maternal outcomes: the World Health Organization multicountry survey on maternal and newborn health. Obstet Gynecol. 2016;127 (4):631-641. doi:10.1097/AOG.0000000000001338

13. Ali AS, Faraag E, Mohammed M. The safety and effectiveness of bakri balloon in the management of postpartum hemorrhage: a systematic review. J Matern Fetal Neonatal Med. 2021;34 (2):300-307. doi:10.1080/14767058.2019.1605349

14. Goffman D, Nathan L, Chazotte C. Obstetric hemorrhage: a global review. Semin Perinatol. 2016;40(2):96-98. doi:10.1053/j. semperi.2015.11.014

15. Belachew J, Eurenius K, Mulic-Lutvica A. Placental location, postpartum hemorrhage and retained placenta in women with a previous cesarean section delivery: a prospective cohort study. Ups J Med Sci. 2017;122(3):185-189. doi:10.1080/03009734.2017.1356405 
16. Lee JY, Ahn EH, Kang S. Scoring model to predict massive post-partum bleeding in pregnancies with placenta previa: a retrospective cohort study. J Obstet Gynaecol Res. 2018;44 (1):54-60. doi:10.1111/jog. 13480

17. Fan D, Xia Q, Liu L. The incidence of postpartum hemorrhage in pregnant women with placenta previa: a systematic review and meta-analysis. PLoS One. 2017;12(1):e0170194. doi:10.1371/journal.pone.0170194

18. Jauniaux E, Bhide A. Prenatal ultrasound diagnosis and outcome of placenta previa accreta after cesarean delivery: a systematic review and meta-analysis. Am J Obstet Gynecol. 2017;217(1):27-36. doi:10.1016/j.ajog.2017.02.050

19. Zeevi G, Tirosh D, Hershkovitz R. Prior cesarean section and placenta accreta spectrum disorders: some clarifications. Arch Gynecol Obstet. 2018;298(2):445-446. doi:10.1007/s00404-0184816-3

20. Rosen T. Placenta accreta and cesarean scar pregnancy: overlooked costs of the rising cesarean section rate. Clin Perinatol. 2008;35 (3):519-529. doi:10.1016/j.clp.2008.07.003

21. Ononge S, Mirembe F, Wandabwa J. Incidence and risk factors for postpartum hemorrhage in Uganda. Reprod Health. 2016;13(1):38. doi:10.1186/s12978-016-0154-8

22. Firmin M, Carles G, Mence B, et al. Postpartum hemorrhage: incidence, risk factors, and causes in Western French Guiana. J Gynecol Obstet Hum Reprod. 2019;48(1):55-60. doi:10.1016/j.jogoh.2018.11.006

23. Keag OE, Norman JE, Stock SJ. Long-term risks and benefits associated with cesarean delivery for mother, baby, and subsequent pregnancies: systematic review and meta-analysis. PLoS Med. 2018;15 (1):e1002494. doi:10.1371/journal.pmed.1002494
24. Gu L, Zhang W, Yang W. Systematic review and meta-analysis of whether cesarean section contributes to the incidence of allergic diseases in children: a protocol for systematic review and meta analysis. Medicine. 2019;98(52):e18394. doi:10.1097/MD.0000000000018394

25. Antony KM, Dildy GA. Postpartum hemorrhage: the role of the maternal-fetal medicine specialist in enhancing quality and patient safety. Semin Perinatol. 2013;37(4):246-256. doi:10.1053/j. semperi.2013.04.004

26. Sentilhes L, Merlot B, Madar H. Postpartum haemorrhage: prevention and treatment. Expert Rev Hematol. 2016;9(11):1043-1061. doi:10.1080/17474086.2016.1245135

27. Kawakita T, Mokhtari N, Huang JC. Evaluation of risk-assessment tools for severe postpartum hemorrhage in women undergoing cesarean delivery. Obstet Gynecol. 2019;134(6):1308-1316. doi:10.1097/ AOG.0000000000003574

28. Sheiner E, Sarid L, Levy A, Seidman DS, Hallak M. Obstetric risk factors and outcome of pregnancies complicated with early postpartum hemorrhage: a population-based study. J Matern Fetal Neonatal Med. 2005;18(3):149-154. doi:10.1080/14767050500170088

29. Blomberg M. Maternal obesity and risk of postpartum hemorrhage. Obstet Gynecol. 2011;118(3):561-568. doi:10.1097/AOG.0b013e31822a6c59

30. Berg CJ, MacKay AP, Qin C, Callaghan WM. Overview of maternal morbidity during hospitalization for labor and delivery in the United States: 1993-1997 and 2001-2005. Obstet Gynecol. 2009;113(5):10751081.
International Journal of Women's Health

\section{Publish your work in this journal}

The International Journal of Women's Health is an international, peerreviewed open-access journal publishing original research, reports, editorials, reviews and commentaries on all aspects of women's healthcare including gynecology, obstetrics, and breast cancer. The

\section{Dovepress}

manuscript management system is completely online and includes a very quick and fair peer-review system, which is all easy to use. Visit http://www.dovepress.com/testimonials.php to read real quotes from published authors. 